\title{
Leptospirosis in a giant anteater (Myrmecophaga tridactyla, Linnaeus, 1758) in Rio de Janeiro Zoo, Brazil
}

\section{Leptospirose em um tamanduá gigante (Myrmecophaga tridactyla, Linnaeus, 1758) no Zoológico do Rio de Janeiro}

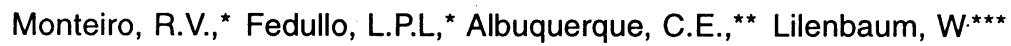

\begin{abstract}
An adult female giant anteater (Myrmecophaga tridactyla) presented leptospirosis in Rio de Janeiro Zoo. Serum samples were collected and agglutinins anti-Leptospira interrogans serovar icterohaemorrhagiae were evidenced. Hemogram and biochemical analysis were compatible with the disease. Therapy was instituted with an association of Penicillin, Streptomycin and Dihydrostreptomycin. No toxic effects of antibiotic association could be noticed and this therapy was considered adequate to treat giant anteater leptospirosis. We suggest giant anteater immunisation against leptospirosis to be implemented in risk areas and further investigation on the vaccination efficacy in this species.
\end{abstract}

Keywords: leptospirosis, anteater, zoo, wildlife.

\section{Resumo}

Uma fêmea adulta de tamanduá gigante (Myrmecophaga tridactyla) apresentou leptospirose no Zoológico do Rio de Janeiro. Amostras de soro foram coletadas e aglutininas anti-Leptospira interrogans serovar icterohaemorrhagiae foram evidenciadas. O hemograma e a análise bioquímica foram compatíveis com a enfermidade. A terapia foi instituída com em associação de penicilina, estreptomicina e dihidroestreptomicina. Não foram observados efeitos tóxicos da associação de antibióticos e esta terapia foi considerada adequada para tratar a leptospirose em tamanduás gigantes. Sugere-se a implementação de imunização contra leptospirose em tamanduás de áreas de risco e maiores investigações acerca da eficiência da vacinação nesta espécie.

Palavras-chave: leptospirose, tamanduá, zoológico, vida selvagem.

\section{Clinical case}

Urban leptospirosis has the rat (Rattus novergicus) as its major reservoir. This species is a healthy host, who spreads leptospires through the urine (Lilenbaum et al., 1993). Leptospirosis outbreaks in urban areas commonly arise after heavy rains and flooding, making rats come out of their refugees and facilitating the contact of other species with contaminated urine.

Leptospires mainly affects kidneys' parenchyma, where they multiply. The clinical signals of the infection are generally related to acute renal insufficiency and uremia. Notwithstanding, lesions could lead to chronic renal insufficiency (Greene, 1997). This paper reports a case of leptospirosis in a giant anteater (Myrmecophaga tridactyla), a Brazilian mammal species belonging to family Edentate.

The animal in focus arrived at Rio de Janeiro Zoo in October 1999. The animal, an adult female, came from wild weighting $24 \mathrm{~kg}$, which is underweight and was deverminated, since
Trichostrongylus sp. was evidenced at coproparasitologic exam. Clinical exam performed by veterinarians did not evidence any sign of disease.

Four months later an area close to the of animal's enclosure was rebuilt together with its sewerage system, causing a transitory increase of rat population in this area and a few days later the animal became less active and hyporetic.

It weighted $26,5 \mathrm{~kg}$ and was bled for hemogram and biochemical analysis, such as blood urea nitrogen (BUN) and creatinine dosage. Immunological tests as ELISA and microscopic agglutination test (MAT) to anti-Leptospira antibodies were performed following Myers (1985). Hemograms were subsequently realized at variable intervals and results are presented on Table 1.

First hemogram $(03 / 13)$ was characterised by a normocytic normochromic anemia, leukocytosis with neutrophilia (with a left shift) and lynphopenia (normal reference values came from Divers, 1986). The urea (BUN) and creatinine results were

\footnotetext{
* MVD, MSc, Rio de Janeiro Zoological Foundation (Fundação RIOZOO).

* Veterinary Student, Universidade Federal Fluminense

***MVD, PhD, Dept. Microbiology, Universidade Federal Fluminense. R. Prof. Hernani Mello, 101. Niterói-RJ, Brasil. CEP 24210-130. Email; MIPWALT@ VM.UFF.BR
} 
Table 1: Successive blood parametc."s of a female giant anteater

\begin{tabular}{lrrrr}
\hline Parameter & $03 / 13 / 00$ & $03 / 27 / 00$ & $04 / 18 / 00$ & $06 / 14 / 00$ \\
\hline RBC (x 10 $/ \mu \mathrm{l})$ & 1.12 & 1.36 & 1.58 & 1.45 \\
\hline Haemoglobin (g/dl) & 9.4 & 11.9 & 14.4 & 11.3 \\
\hline PCV (\%) & 28 & 34 & 43 & 34 \\
MCV (fl) & 25 & 25 & 27.2 & 23.4 \\
\hline MCH (pg) & 8.3 & 8.3 & 9.1 & 7.7 \\
\hline MCHC (\%) & 33.5 & 33.5 & 33.4 & 33.2 \\
\hline WBC (x10 $/ \mu \mathrm{l})$ & 14.0 & 14.0 & 16.05 & 9.0 \\
\hline Segmented neutrophil (\%) & 65 & 59 & 68 & 73 \\
\hline Band neutrophil (\%) & 15 & 15 & 14 & 8 \\
\hline Myelocytes (\%) & 1 & - & - & - \\
\hline Lymphocytes (\%) & 18 & 24 & 17 & 18 \\
\hline Monocytes (\%) & 1 & 2 & & 1 \\
\hline Eosinophils (\%) & - & - & 1 & - \\
\hline
\end{tabular}

RBC: red blood cells; PCV: packed cell volume; MCV: mean cell volume; $\mathrm{MCH}$ : mean cell haemoglobin;

MCHC: mean cell haemoglobin concentration; WBC: white blood cells.

$27.2 \mathrm{mg} / \mathrm{dl}$ and $0.72 \mathrm{mg} / \mathrm{dl}$ respectively; although normal values for this species are unknown, these results were considered within reasonably limits. In relation to the immunological tests, while ELISA was negative, the MAT presented positive reaction to Leptospira interrogans serovar icterohaemorrhagiae to the titre of 200. Since MAT is still the recommended test for the diagnosis of leptospirosis (Myers, 1985) and the clinical and haematological aspects were compatible with this disease, was concluded that this anteater presented an acute leptospirosis determined by that serovar. Unfortunately, attempts to isolate Leptospira from the urine was not assayed, since the difficulty of catheterization observed in giant anteaters precludes the obtaining of sterile samples.

The animal was treated with an association of streptomycin sulphate $(5 \mathrm{mg} / \mathrm{Kg})$, dihydrostreptomycin sulphate $(5 \mathrm{mg} / \mathrm{kg})$, potassium penicillin, benzathine penicillin and procaine penicillin (combined doses of $30.000 \mathrm{UI} / \mathrm{kg}$ ). Drugs were administrated SID in a 48 hours interval, via blowpipe, during a five applications cycle. No signs of antibiotic toxicity were noticed during treatment.

During that treatment the animal showed a gradual improvement in its clinical condition, feeding better and behaving more active. Hemogram performed after the last day

\section{References}

BYWATER, R.J. Aminoglycoside and aminocyclitol antibiotics. In: BRANDER, G.C.; PUGH, D.M.; BYWATER, R.J. and JENKINS, W.L. Veterinary applied pharmacology and therapeutics. $5^{\text {th }}$ ed., London: Bailliére Tindall, 1991. p. 452-460.

DIVERS, B.J. Edentata. In: FOWLER, M.E. (Ed.). Zoo and Wild Animal Medicine. $2^{\text {nd }}$ ed., Philadelphia, Pennsylvania: W.B. Saunders Co., 1986. p. 621-630.

GREENE, C.E. Moléstias Bacterianas. In: EITINGER, S.J. and FELDMAN, E.C. (Eds.). Tratado de Medicina Interna Veterinária. 4. ed. São Paulo: Manole,. 1997. p. 530-542. of the therapy, March 27th., presented a slight improvement (Table 1), while the leukogram was similar to the previous one. Urinalysis was performed (Combur10 Test ${ }^{\circledR}$ ), which presented proteinuria and hematuria (protein $30 \mathrm{mg} / \mathrm{dl}$ and blood 50 erythrocytes $/ \mathrm{ml}$ ). These probably characterised renal damage, although a slight local tissue bleeding due to urethra's catheterization cannot be excluded.

A new serum sample for MAT and a total blood sample for hemogram was obtained three weeks after the end of the therapy (April 18 ${ }^{\text {th }}$, Table 1). MAT presented a negative result and, although the hemogram did not evidence a significant improvement, based on clinical findings was decided to interrupt antibiotics administration. Another hemogram was done in June $14^{\text {th }}$. Leukocytosis disappeared, while band neutrophils were still present (Table 1). After this test was decided to stop handling the animal, in order to avoid more stress.

Penicillin and streptomycin are recommended in literature as a first choice to treat mammals with leptospires infection, while the dihydrostreptomycin is recommended to clear the carrier status (Greene, 1997). It was concluded that although the antibiotic association was capable to treat giant anteater of leptospirosis (apparently without toxic effects at this dosage), a probable renal damage was evidenced. Chronic nonregenerative anemia (as in this animal) is commonly seen subsequently to kidney parenchyma damage, due to low level of renal eritropoitin secretion (Polzin et al., 1997).

Renal damage in this animal could be from Leptospira action itself or from antibiotic-induced nephrotoxicity. The latter are usually related to streptomycin - dihydrostreptomycin prolonged treatment (Bywater, 1991), which was not the present case. Thus, Leptospira seems to be the major responsible for the apparent kidney aggression. This agent probably came from contaminated rat urine, moreover when serovar icterohaemorrhagiae is major implicated on urban leptospirosis (Lilenbaum et al., 1993). Rat control must be emphasised in the Zoo, mainly in giant anteater enclosures, which are typically grass covered, giving shelter to rats. Therefore, giant anteater immunisation against leptospirosis is suggested in risk areas, as well as further investigation on the vaccination efficacy in this species.

LILENBAUM, W.; RIBEIRO, V.; Martin, E. andBISPO, V. Estudo sorológico para detecção de anticorpos anti-leptospira em Rattus norvegicus de Duque de Caxias, Rio de Janeiro, Brasil. Revista Latinoamericana de Microbiologia, v. 35, n. 4, p. 357-360, 1993.

MYERS, D.M. Manual de Métodos para el diagnóstico de la leptospirose. Centro Panamericano de Zoonoses, Nota Técnica, 1985, p. 30.

POLZIN, D.J.; OSBORNE, C.A.; BARTGES, J.W.; JAMES, C.M. and CHURCHILL, J.A. Insuficiência Renal Crônica. In: ETTINGER, S.J. and FELDMAN, E.C. (Eds.). Tratado de Medicina Interna Veterinária. 4. ed. São Paulo: Manole, 1997. p. 2.394-2.431. 